\title{
The effectiveness of herbicides in soybean cultivation
}

\author{
Alexey Dykun ${ }^{1}$, \\ Vladimir Zherebko ${ }^{1}$, \\ Maria Dykun ${ }^{2}$ \\ ${ }^{1}$ Department of Agriculture and Herbology, \\ National University of Life \\ and Environmental Sciences, \\ 15 Heroes Defense Street, \\ 03041 Kyiv, Ukraine \\ Email:Allasaker823@gmail.com \\ ${ }^{2}$ Institute of Plant Physiology \\ and Genetics of NAS of Ukraine, \\ 31/17 Vasylkivska Street, \\ 03022 Kyiv, Ukraine
}

The necessity to improve systems of soybean crop protection from weeds as a critical factor in further increasing of crop yields and improving of food quality conditioned the topicality of a problem raised in this publication. In this regard, we directed this article on the determination of biological activity of individual post-emergence herbicides in relation to the most common and harmful weed species and establishing of their technical and economic efficiency under growing of soybeans in the Right-Bank Forest-Steppe of Ukraine. The effectiveness of chemical weeding of crops with preparations bentazone, imazamox and bentazone+imazamox in two-year field experiments in a stationary crop rotation at the Agronomic Research Station of the National University of Life and Environmental Sciences of Ukraine was analysed.

It is established that the application of post-emergence herbicide bentazone+imazamox, which at the expense of high biological activity significantly reduced density of widespread and relatively chemicalresistant weeds at a mixed type of soybean crop weediness, is effective enough. Twofold application of $0.75 \mathrm{l} \mathrm{ha}^{-1}$ of the herbicide in a tank mixture with $1.01 \mathrm{ha}^{-1}$ of the surfactant Metolat with a two-week interval in the phase of two or three true leaves on soybeans was more effective. It resulted in a loss of $89 \%$ of gray bristle (Setaria glauca (Poir.) Roem. \& Schult), $65 \%$ of common chicken millet (Echinochloa crus-galli (L.) P. Beauv.) and almost full destruction of broadleaf species (99\%) with $97 \%$ reduction of raw weed biomass. However, the soybean yield averaged $3.82 \mathrm{t} \mathrm{ha}^{-1}$ over 2 years that is by $34 \%$ higher than in the control option without chemical weeding. Application of the herbicide did not reduce protein and oil content.

Keywords: soybean, weeds, post-emergence herbicides, biological activity, efficacy of use, productivity

\section{INTRODUCTION}

Herbicides are an integral part of intensive soybean cultivation technologies. In weed control, agrarians increasingly often prefer post-emergence herbicides, which allow selecting the most effective product considering assessment of the actual type of weeding, and their biological activity does not depend on the type and humidity of the soil. The use of post-emergence herbicides with an aim to reduce tillage changed the composition of weed populations (Vencill et al., 2012). Several species of dominant gramineous and broadleaved weeds pose a serious threat to soybeans, the most dangerous of which are Echinochloa crus-galli (L.) P. Beauv., Setaria glauca (Poir.) Roem. \& Schult, Amaranthus retroflexus L. and Chenopodium album L. (Smatana et al., 2016). The reasons why these weed species are very spread and problematic in Europe and in the world are their high 
competitive performance, strong seed productivity and multiple resistance (Soltys et al., 2013; Heap, 2017). Ch. album is one of the most aggressive and harmful weeds and a vicious cosmopolitan litter of almost all cultivated plants, endowed with unique biological features. In addition to its high reproductive capacity, ability to germinate and vegetate in a wide range of hydrothermal conditions, this plant has developed abiotic resistance to stresses, mechanisms of effective nutrient absorption and allelopathic influence on competitive agrocenosis plants (Bajwa et al., 2019), and protection against chemical irritants due to formation of cuticular and cutic waxes on its stems and leaves. The evolution of large-scale herbicide resistance, appearance and rapid spread of resistant weed species significantly complicate their control and threaten global agricultural production (Storkey et al., 2012; Karimmojeni et al., 2014; Ghanizadeh, Harrington, 2017).

It is possible to prevent the emergence of new resistant populations and ensure a sustainable and reliable control of weed flora by using alternative composite herbicides or tank mixtures of selective products with different active substances, expanding thereby the range of sensitive weeds and significantly increasing herbicidal activity under a synergistic action of components (Aulakh et al., 2012; Norsworthy et al., 2012; Jadhav, Kashid, 2019; Meseldžija et al., 2020). In particular, a significant number of researchers indicate a high efficiency of the bentazone and imazamox herbicide composition in soybean crops, which reliably eliminates a wide range of contaminants without phytotoxic effects on the crop and increases its productivity (Williams, Nelson, 2014). A high biological activity of the mixture is related with the synergistic effect of its components.

Bentazone is a popular contact herbicide of the benzothiadiazone group with pronounced biological activity against broadleaved and sedgy weeds conditioned by irreversibility of the process of blocking the photosynthetic transport of electrons in the light phase of photosynthesis. The unique mechanism of action specifies a high selectivity and effectiveness of the product (Soltani et al., 2013); however, a weak herbicidal activity against gramineous weeds significantly narrows the possibility of its independent use.
Imazamox is a highly selective post-emergence herbicide derived from imidazolinones that effectively controls a wide range of gramineous and broadleaved weeds in soybean crops. The action mechanism of the herbicide is based on suppression of the regulatory function of the enzyme acetolactate synthase (ALS) and disruption of the biosynthesis of specific essential amino acids (Kraemer et al., 2012; Gupta et al., 2017), thus breaking the formation of proteins and nucleic acids. Imazamox has a systemic effect through leaves and roots at low doses of the herbicide. However, significant risks of phytotoxicity manifestations exist when using imidazolinone products in legumes (Williams, Nelson, 2014; Walsh et al., 2015; Marchioretto, Magro, 2017). In addition, there are some caveats regarding the aftereffects of imazamox on subsequent crops in the crop rotation, as well as possible reduction of efficiency in weed populations resistant to ALS inhibitors. In an herbicide mixture, imazamox expands the range of vulnerable weeds by gramineous plants, while bentazone reduces the toxic effects of imidazolinones on soybeans by reducing a ratio of production and translocation of photoassimilates and weakening of the uptake and transport of ALS in the plant phloem.

With the appearance of the combined postemergence herbicide bentazone+imazamox on the world agricultural market, the technology of integrated application of both products is significantly simplified.

The combination of different mechanisms of the action of bentazone and imazamox allows the herbicide bentazone+imazamox to affect different areas of biochemical bonds of weeds, which is an important element of the anti-resistance program.

The herbicide is positioned as a highly active and highly selective broad-spectrum one. Currently, bentazone+imazamox is the most promising post-emergence product recommended for soybeans in Ukraine, Russia and EU countries, including Lithuania.

Considering a significant dependence of the technical and economic efficiency of herbicides on soil and climatic conditions of cultivation, the level of their activity under actual weeding, the establishment of optimal rates and timing of application is important and contributes to 
increasing the profitability of soybean production and economic efficiency. Therefore, the research goal was finding out the biological activity of the combined post-emergence herbicide bentazone+imazamox against weed populations at different application rates, the determination of the nature of herbicide's effect on the yield and quality of soybean seeds, and the establishment of the expediency of its application for an effective control of common weeds.

\section{MATERIALS AND METHODS}

The research aimed at establishment of the efficiency of post-emergence herbicides application that was carried out in a field experiment in the stationary crop rotation at the Laboratory of Selection and Seed Production of the Agronomic Research Station, National University of Life and Environmental Sciences of Ukraine for 20182019. The experiment design included the use of three post-emergence herbicides in soybean crops (Table 1).

For the determination of herbicidal activity and the establishment of optimal rates and frequency of application of the two-component post-emergence herbicide Corum (a.i. bentazone, $480 \mathrm{~g} \mathrm{l}^{-1}+$ imazamox, $22.4 \mathrm{~g} \mathrm{l}^{-1}$ ) registered in Ukraine (with a consumption of 1.25-2.0 $1 \mathrm{ha}^{-1}$ ), the efficiency of single (1.5-2.5 $\mathrm{l} \mathrm{ha}^{-1}$ ) and double application $\left(0.75 \mathrm{l} \mathrm{ha}^{-1}\right)$ with a two-week interval was studied. The herbicide was applied in a tank mixture with the surfactant Metolate at the recommended rate of $1.0 \mathrm{l} \mathrm{ha}^{-1}$. The reference products Basagran (a.i. bentazone, $480 \mathrm{~g} \mathrm{l}^{-1}$ ) and Pulsar (a.i. imazamox,
$40 \mathrm{~g} \mathrm{l}^{-1}$ ) were tested at the recommended rates of 2.5 and $1.01 \mathrm{ha}^{-1}$, respectively.

The accounting area of the plot was $30 \mathrm{~m}^{2}$. Repetition was quadruple. Placement of options was randomized. The soil of the experimental field was typical low-humus medium loam black earth, with the humus content of $4.43 \%, \mathrm{pH}_{\mathrm{KCl}}$ was $6.1-7.0$, the absorption capacity was $31.9 \mathrm{mg}$-eq $100 \mathrm{~g}^{-1}$ of soil, the content of easily hydrolyzed nitrogen was $10.6-11.4 \mathrm{mg} 100 \mathrm{~g}^{-1}$ of soil.

The agricultural technique in the experiment was the one generally accepted for the ForestSteppe zone of Ukraine and included double stubbling with disc harrows with subsequent plowing and two pre-sowing cultivations with harrowing, under which compound mineral fertilizers were applied at the rate of $30 \mathrm{~kg} \mathrm{ha}^{-1}$ NPK. Corn for grain was a precursor of soybean in all years of research. Madison soybean inoculated seeds were sown at the optimum soil temperature in the first decade of May with a seeder Great Plains 3P606NT (Great Plains, USA) at the seeding rate of about 500 thousand similar seeds $\mathrm{ha}^{-1}$ and a depth of wrapping of $4-5 \mathrm{~cm}$. The herbicides were applied by means of a hand-held accumulator sprayer BS125 (Foresta, China) with the flow rate of $250 \mathrm{l} \mathrm{ha}^{-1}$ and the working pressure of $300 \mathrm{kPa}$ in the phase of the first true leaf on soybeans. The re-treatment of Corum with the herbicide according to the experiment design was performed at the interval of 14 days. Harvesting and accounting were carried out separately for each plot with subsequent conversion to $\mathrm{tha}^{-1}$.

Determination of the species composition and density of the weed component in the experimental

Table 1. Treatments of application of herbicides

\begin{tabular}{|c|c|c|c|}
\hline Treatment & Trade name & Active ingredient & $\begin{array}{c}\text { Dose } \\
\text { of the applied her- } \\
\text { bicide }\left(l \cdot \mathrm{ha}^{-1}\right)\end{array}$ \\
\hline 1 & Untreated control & - & - \\
\hline 2 & Basagran AS (aquatic solution) & Bentazone $48 \%$ & 2.5 \\
\hline 3 & Pulsar WSC (water-soluble concentrate) & Imazamox $4 \%$ & 1.0 \\
\hline 4 & Corum $^{\circledast}$ LC (liquid concentrate) & Bentazone $48 \%$ + Imazamox $2.24 \%$ & 1.5 \\
\hline 5 & Corum $^{\circledast}$ LC & Bentazone $48 \%$ + Imazamox $2.24 \%$ & 2.0 \\
\hline 6 & Corum $^{\circledR}$ LC & Bentazone $48 \%$ + Imazamox $2.24 \%$ & 2.5 \\
\hline 7 & Corum $^{\circledast} \mathrm{LC}$ & Bentazone $48 \%$ + Imazamox $2.24 \%$ & $\begin{array}{l}\text { twofold application } \\
\text { of } 0.75\end{array}$ \\
\hline
\end{tabular}


options was performed by double accounting of weediness by the quantitative and quantitativeweight method twice during the growing season - 30 days after application of herbicides and in the phase R6 (full seed). Weed counting was performed using a $1-\mathrm{m}^{2}$ counting frame three times for each replication variant. The last accounting was recorded with consideration of raw weed biomass without a root system.

The selectivity (phytotoxicity) of herbicides was determined by a 9-point EWRS toxicity scale.

A biochemical analysis of soybean seeds was carried out in laboratory conditions using an infrared analyzer Inframatic 8600 (Perten, Switzerland). The agrometeorological conditions, which included decadal values of air temperature and precipitation, were analysed according to the data of the two nearest meteorological stations.

The statistical analysis of yield and protein and oil content in soybean seeds was performed by analysis of variance (ANOVA) dispersion analysis using the software package Excel.

\section{RESULTS AND DISCUSSION}

The agro-climatic conditions of the growing season are the decisive factor influencing the productivity of the crop and in particular the efficiency of measures to protect it. In recent years, with the global climate change, even in the ForestSteppe Zone of Ukraine there is an acute shortage of moisture, which at high summer temperatures has a negative impact on yields and leads to a gradual shifting of the 'soybean belt' to the north of the country.

During the research years, the actual precipitation level was much lower than the long-term average one.

In 2019, in the critical period for soybeans (phase of flowering and full seed), the amount of precipitation was only a third of the long-term norm, which led to a decrease in yield. The hydrothermal conditions of 2018 were more optimal when during July the one-and-a-half-month precipitation rate fell relatively evenly, which provided the necessary water balance during the period of crop formation and contributed to its significant increase. Sufficient soil moisturization during the application of herbicides had a positive effect on their biological activity, because the ef- fectiveness of imidazolinones that also act through the soil and root system of weeds increases with sufficient moisture in the surface layer of the soil, where a reliable 'herbicidal screen' is created, restraining the emergence of subsequent waves of weeds. The level of thermal resources of both years was quite enough for the full growth and development of the crop.

Soybeans are too sensitive to weediness level. The economic threshold of harmfulness ensues in the presence of several plants of dominant weeds per $1 \mathrm{~m}^{-2}$.

A mixed type of weediness was observed in the experimental fields. The weed component of the soybean agrocenosis was based on annual gramineous and broadleaved species belonging to the late spring type. The general structure of weeding was dominated by dicotyledonous annual species, which accounted for about two-thirds of the segetal plants population. Gramineous plants accounted for $25 \%$ and perennials for less than $4 \%$ of the total number of weeds. Broadleaved weeds were represented mainly by five species, among which Ch. album, $A$. retroflexus, Persicaria lapathipholia (L.) Delarbre and Fallopia convolvulus (L.) Á. Löve were the most common, which summarily exceeded a half of the total number of contaminants (Fig. 1).

Two common species, S. glauca and E. crusgalli, represented a gramineous component of the weed population, while perennials (Sonchus arvensis L. and Elymus repens (L.) Gould) were relatively small.

The analysis of herbicidal activity of products was performed on four species of weed flora, which in terms of number, competitiveness and biological productivity are more harmful in the ForestSteppe Region of Ukraine, namely Ch. album, A. retroflexus, S. glauca and E. crus-galli. The weed count results showed a significant predominance of Ch. album and S. glauca, which together accounted for almost $60 \%$ of the total quantity of weeds. At the same time, the population of Ch. album was more numerous, the density of which in options without the use of herbicides reached 30-33 plants $\mathrm{m}^{-2}$ (Table 2).

The total number of weeds in the untreated control fluctuated markedly during the growing season, reaching minimum values before harvesting, which is the evidence of fierce interspecies 


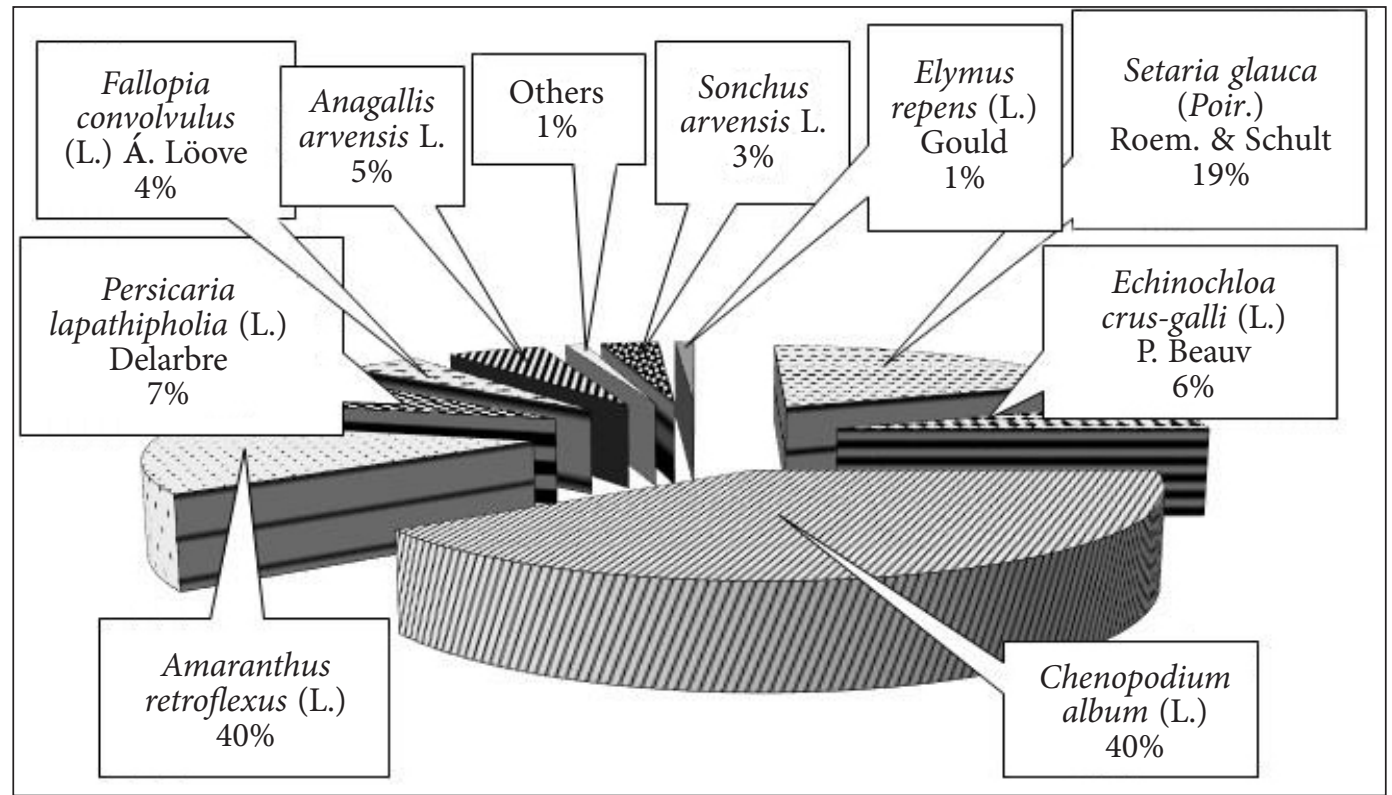

Fig. 1. A specific structure of weediness of the experimental field ${ }^{*}$

* Significant at the $5 \%$ level according to a Fisher's protected LSD test at $p<0.05$.

Table 2. The density of weed component and the technical efficiency of herbicides in soybean crops

\begin{tabular}{|c|c|c|c|c|c|c|c|}
\hline \multirow[b]{2}{*}{ Treatment } & \multicolumn{4}{|c|}{ Weed species, units. $\mathrm{m}^{-2}$} & \multicolumn{3}{|c|}{ Total loss } \\
\hline & कू & 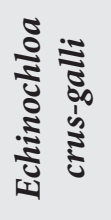 & 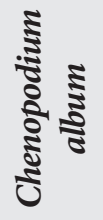 & 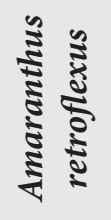 & $\Sigma$, units $\cdot \mathrm{m}^{-2}$ & $\%$ & $\begin{array}{c}\text { Biomass, } \\
\mathrm{g} \mathrm{m}^{-2}\end{array}$ \\
\hline \multicolumn{8}{|c|}{ In 30 days after application of herbicides } \\
\hline Untreated control & 16.0 & 5.1 & 32.9 & 11.2 & 65.2 & 0 & \\
\hline Bentazone, $2.51 \mathrm{ha}^{-1}$ & 4.0 & 2.4 & 2.4 & 1.1 & 9.9 & 85 & \\
\hline Imazamox, $1.01 \mathrm{ha}^{-1}$ & 2.1 & 1.9 & 2.3 & 1.2 & 7.5 & 88 & \\
\hline Bentazone+imazamox, $1.51 \mathrm{ha}^{-1}$ & 1.7 & 2.4 & 1.7 & 1.1 & 6.9 & 89 & \\
\hline Bentazone+imazamox, $2.01 \mathrm{ha}^{-1}$ & 1.6 & 2.1 & 1.3 & 0.9 & 5.9 & 91 & \\
\hline Bentazone+imazamox, $2.51 \mathrm{ha}^{-1}$ & 1.4 & 1.9 & 1.0 & 0.5 & 4.8 & 93 & \\
\hline $\begin{array}{c}\text { Bentazone+imazamox, } \\
\text { twofold application of } 0.75 \mathrm{ha}^{-1}\end{array}$ & 1.4 & 1.7 & 0.6 & 0.2 & 3.9 & 94 & \\
\hline LSD at $p<0.05$ & 1.77 & 1.10 & 4.34 & 1.26 & & & \\
\hline \multicolumn{8}{|c|}{ During the stage R6 (full seed) } \\
\hline Untreated control & 10.8 & 4.2 & 29.8 & 8.6 & 53.4 & 0 & 1190 \\
\hline Bentazone, $2.51 \mathrm{ha}^{-1}$ & 3.2 & 2.0 & 2.5 & 1.0 & 8.7 & 84 & 309 \\
\hline Imazamox, $1.01 \mathrm{ha}^{-1}$ & 1.4 & 1.8 & 1.5 & 0.6 & 5.3 & 90 & 153 \\
\hline Bentazone+imazamox, $1.51 \mathrm{ha}^{-1}$ & 1.7 & 1.6 & 1.7 & 0.8 & 5.8 & 89 & 129 \\
\hline Bentazone+imazamox, $2.01 \mathrm{ha}^{-1}$ & 1.3 & 1.0 & 1.0 & 0.7 & 4.0 & 93 & 91 \\
\hline Bentazone+imazamox, $2.51 \mathrm{ha}^{-1}$ & 1.1 & 1.1 & 0.5 & 0.3 & 3.0 & 94 & 74 \\
\hline $\begin{array}{l}\text { Bentazone+imazamox, twofold } \\
\text { application of } 0.751 \mathrm{ha}^{-1}\end{array}$ & 1.2 & 1.5 & 0.2 & 0.1 & 3.0 & 94 & 41 \\
\hline LSD at $p<0.05$ & 1.40 & 0.88 & 5.90 & 1.26 & & & 82.09 \\
\hline
\end{tabular}


competition for life factors. Ch. album was the most competitive, reducing their quantity by only $10 \%$, while this number was twice as high for A. retroflexus, and thrice as high for S. glauca.

Herbicides significantly affected the overall weediness of the experimental options. In 30 days after chemical weeding, the total number of weeds decreased by $85-94 \%$, where the best efficiency was provided by the combined preparation bentazone+imazamox at the rates of 2.0-2.5 $1 \mathrm{ha}^{-1}$ and with double application of about $0.75 \mathrm{l} \mathrm{ha}^{-1}$. The post-emergence herbicide imazamox at the recommended rate reduced their number by $88-90 \%$. The herbicidal activity of bentazone was by $3-6 \%$ lower. The analysis of the phytotoxic effects of herbicides on certain weed species showed that they were more efficient against broadleaved weeds (Fig. 2).

Under the influence of bentazone, the loss of A. retroflexus reached $88 \%$, with $92 \%$ for Ch. album, and $70 \%$ and $52 \%$ for the gramineous weeds S. glauca and E. crus-galli, respectively. The nature of action of the other two herbicides was identical. Imazamox reduced the density of broadleaved weeds by $93-95 \%$, and bentazone+imazamox by
91 to $99 \%$ at different rates and frequency of application. At the same time, the efficiency of these post-emergence herbicides regarding gramineous weeds was significantly lower. E. crus-galli was more resistant to herbicide effects, as its loss did not exceed $76 \%$. The individual sensitivity of this weed largely depends on the conditions of natural selection under the pressure of a pesticidal background (Claerchout et al., 2015). The species S. glauca appeared much more vulnerable. Imazamox at the rate of $1.01 \mathrm{ha}^{-1}$ reduced its weediness by $87 \%$, and bentazone+imazamox at the rate of $2.5 \mathrm{l} \mathrm{ha}^{-1}$ with two consecutive applications at the rate of $0.751 \mathrm{ha}^{-1}$ by $90 \%$ and $89 \%$, respectively. Other application rates were less effective.

The high biological activity of the herbicide bentazone+imazamox against gramineous and dicotyledonous annual weeds is explained by the strong and long-term contact-systemic action of the active ingredients and the positive effect of the adjuvant Metolate, which is used together with the herbicide according to the manufacturer's recommendations in the rate of $1.01 \mathrm{ha}^{-1}$. Reducing of the surface tension and contact angle of the sprayed working solution improves the coverage

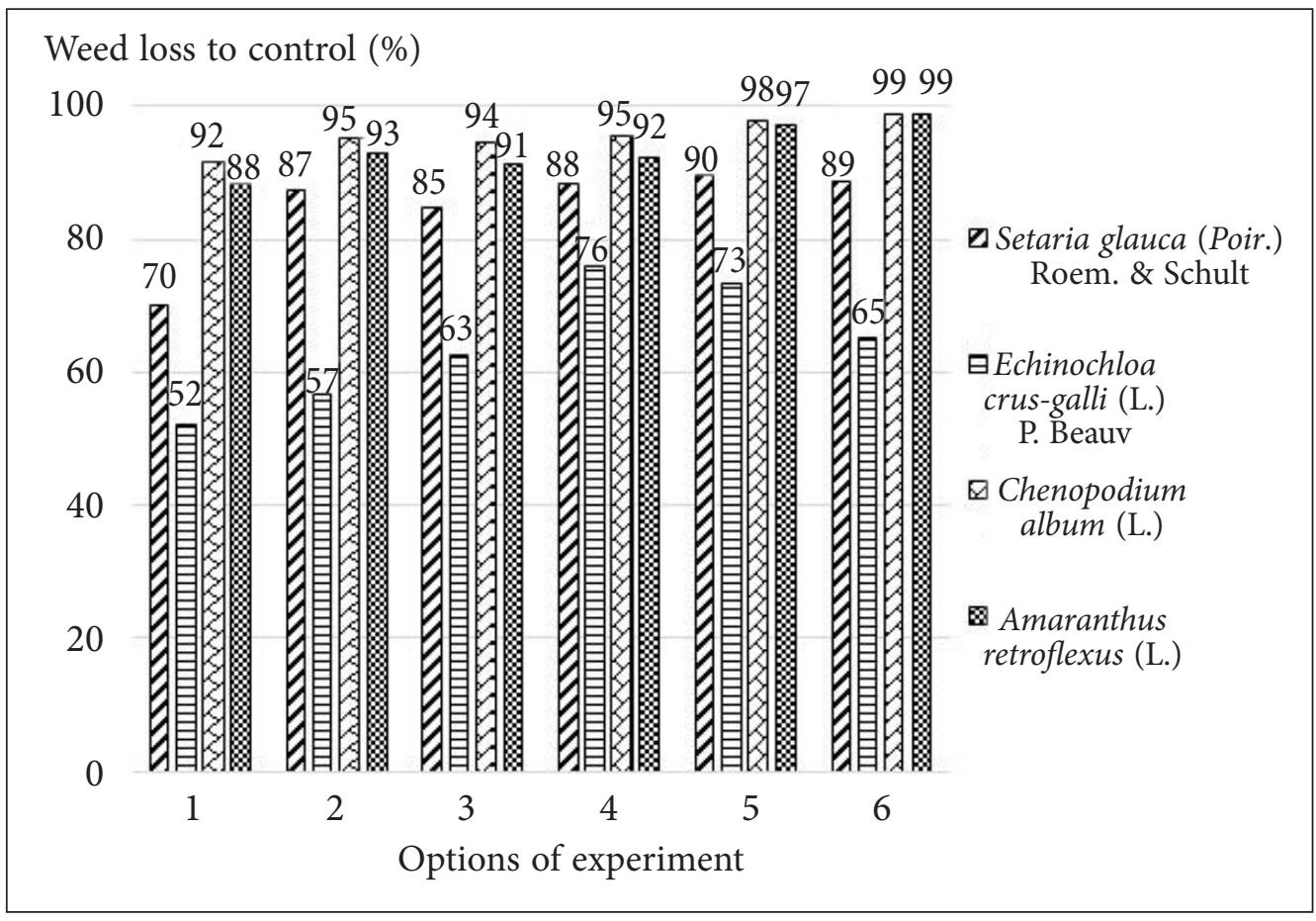

Fig. 2. Biological efficacy of post-emergence herbicides against cereal and dicotyledonous weeds. 1 is bentazone $-2.51 \cdot \mathrm{ha}^{-1} ; 2$ isimazamox $-1.01 \cdot \mathrm{ha}^{-1} ; 3$ isbentazone+imazamox $-1.51 \cdot \mathrm{ha}^{-1}$; 4 is bentazone+imazamox $-2.0 \mathrm{l} \cdot \mathrm{ha}^{-1}$; 5 is bentazone+imazamox $-2.5 \mathrm{l} \cdot \mathrm{ha}^{-1}$; 6 is bentazone+imazamox twofold application of $0.75 \mathrm{l} \cdot \mathrm{ha}^{-1}$ 
of the leaves therewith and the absorption of the herbicide, which is especially important for the contact bentazone, which moves poorly in plants (Gitsopoulos et al., 2014). The alkaline reaction of surfactants leads to partial dissolution of cuticular waxes on the surface of the epidermis and significantly increases the permeability of active substances into living tissues of weeds. This is very relevant for Ch. album, the aboveground part of which is completely covered with a thick low-permeable cuticle layer, which is important to increase resistance to herbicides in dry windy weather and elevated temperatures (Shvartau, Mikhals'kaya, 2013). This layer is a significant barrier to penetration of active pesticide ingredients into living tissues and conduction systems and is very important for increasing of weed populations resistance to herbicides (TafollaArellano et al., 2013; Ivaschenko, Ivaschenko, 2019).

Considering the high efficiency of the herbicide bentazone+imazamox, which is essentially a chemical combination of bentazone and imazamox, one can talk about their synergistic effect, which enhances the herbicidal activity of each of the components. This conclusion is confirmed by our data regarding the reduction of raw biomass of weeds under the effect of herbicides (Fig. 3).
Bentazone reduced the raw weed biomass by $74 \%$, for imazamox this figure was slightly higher $(87 \%)$. At the same time, bentazone+imazamox reduced the mass of weeds by $89 \%$ even at the minimum application rate $\left(1.51 \mathrm{ha}^{-1}\right)$. When the application rate of the product was increased to $2.5 \mathrm{l} \mathrm{ha}^{-1}$, the mass of weeds decreased by $94 \%$, and after two consecutive treatments at a rate of $0.75 \mathrm{l} \mathrm{ha}^{-1}$ by $97 \%$, which is by $23 \%$ higher compared to bentazone.

The effectiveness of weed control is one of the decisive factors of soybean crop productivity, as it directly affects the supply of crops with light, moisture and nutrients. With herbicide protection of crops, a significant increase in crop yield was observed, in particular, with double application of the herbicide bentazone+imazamox at the rate of $0.75 \mathrm{l} \mathrm{ha}^{-1}$, the average yield was higher by $52 \%$ compared to the control while saving $1.3 \mathrm{t} \mathrm{ha}^{-1}$ of the potential seed yield (Table 3 ).

The soybean yield $\left(\mathrm{t} \mathrm{ha}^{-1}\right)$ and the content of protein and oil in soybeans (\%) followed by the same letter are not significantly different at $p<0.05$.

The high effectiveness of the herbicide bentazone+imazamox has been previously reported in the publications of other researchers (Delchev, Barakova, 2018; Ivanov, 2019).

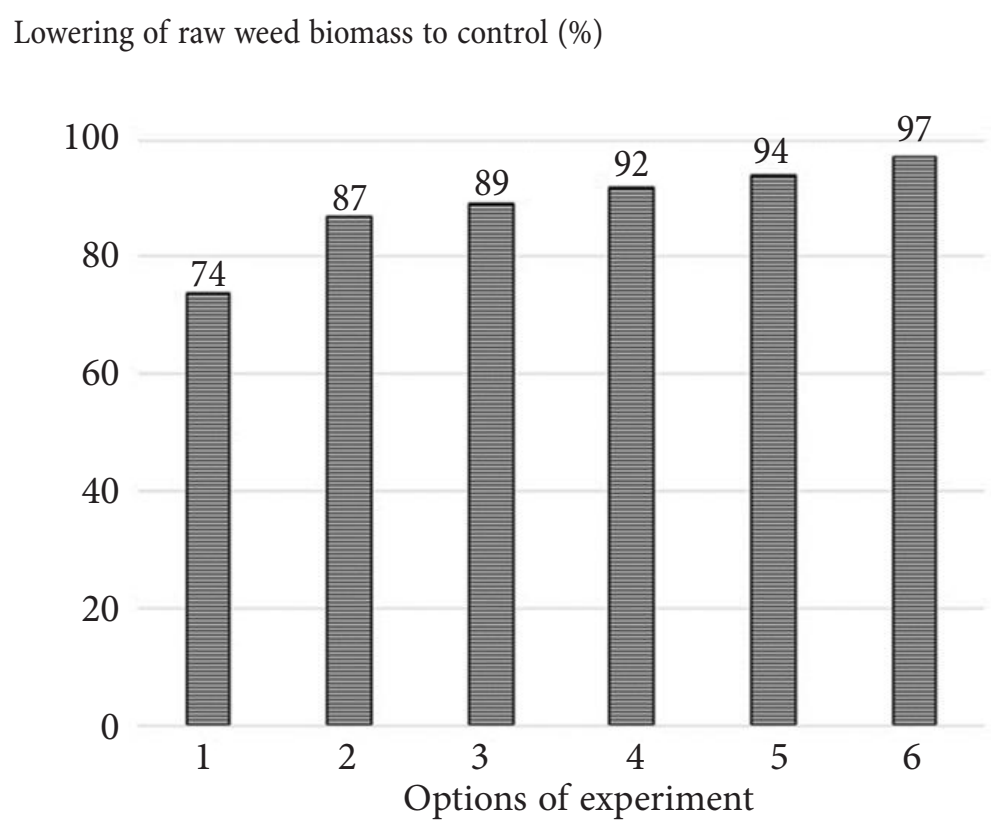

Fig. 3. Reduction of weed biomass by post-emergence herbicides. 1 is bentazone $-2.5 \mathrm{l} \cdot \mathrm{ha}^{-1}$; 2 is imazamox $-1.0 \mathrm{l} \cdot \mathrm{ha}^{-1}$; 3 is bentazone+imazamox $-1.5 \mathrm{l} \cdot \mathrm{ha}^{-1}$; 4 is bentazone+imazamox $-2.01 \cdot \mathrm{ha}^{-1}$; 5 is bentazone+imazamox $-2.51 \cdot \mathrm{ha}^{-1}$; 6 is bentazone+imazamox twofold application of $0.75 \mathrm{l} \cdot \mathrm{ha}^{-1}$ 
Table 3. Influence of herbicides on the yield and the protein and oil content in soybean seeds

\begin{tabular}{c|c|c|c|c|c|c}
\hline \multirow{2}{*}{ Treatment } & \multicolumn{4}{|c|}{ Soybean yield, t.ha-1 } & \multicolumn{2}{c}{ Content, \% } \\
\cline { 2 - 7 } & $\mathbf{2 0 1 8}$ & $\mathbf{2 0 1 9}$ & Average & Saved crop & Protein & Oil \\
\hline Untreated control & $3.33 \mathrm{c}$ & $1.70 \mathrm{~b}$ & $2.52 \mathrm{c}$ & - & $42.9 \mathrm{a} \pm 0.5$ & $20.0 \mathrm{~b} \pm 0.1$ \\
\hline Bentazone, $2.51 \mathrm{ha}^{-1}$ & $4.49 \mathrm{bc}$ & $2.21 \mathrm{ab}$ & $3.35 \mathrm{bc}$ & 0.83 & $41.8 \mathrm{dc} \pm 0.2$ & $20.4 \mathrm{a} \pm 0.2$ \\
\hline Imazamox, $1.01 \mathrm{ha}^{-1}$ & $4.83 \mathrm{ab}$ & $2.32 \mathrm{ab}$ & $3.58 \mathrm{ab}$ & 1.06 & $41.6 \mathrm{~d} \pm 0.2$ & $20.4 \mathrm{a} \pm 0.2$ \\
\hline Bentazone+imazamox, $1.51 \mathrm{ha}^{-1}$ & $4.97 \mathrm{ab}$ & $2.29 \mathrm{ab}$ & $3.63 \mathrm{ab}$ & 1.11 & $42.7 \mathrm{ab} \pm 0.2$ & $20.2 \mathrm{ab} \pm 0.1$ \\
\hline Bentazone+imazamox, $2.0 \mathrm{l} \mathrm{ha}^{-1}$ & $5.04 \mathrm{ab}$ & $2.43 \mathrm{ab}$ & $3.74 \mathrm{ab}$ & 1.22 & $42.0 \mathrm{bc} \pm 0.3$ & $20.4 \mathrm{a} \pm 0.2$ \\
\hline Bentazone+imazamox, $2.51 \mathrm{ha}^{-1}$ & $4.98 \mathrm{ab}$ & $2.41 \mathrm{ab}$ & $3.70 \mathrm{ab}$ & 1.18 & $42.4 \mathrm{ab} \pm 0.2$ & $20.4 \mathrm{a} \pm 0.1$ \\
\hline Bentazone+imazamox, twice of $0.751 \mathrm{ha}^{-1}$ & $5.16 \mathrm{a}$ & $2.48 \mathrm{a}$ & $3.82 \mathrm{a}$ & 1.30 & $42.2 \mathrm{bc} \pm 0.7$ & $20.3 \mathrm{ab} \pm 0.1$ \\
\hline LSD at $p<0.05$ & 0.34 & 0.38 & 0.29 & - & 0.39 & 0.16 \\
\hline
\end{tabular}

Yields were significantly lower for the options with bentazone $\left(3.35 \mathrm{t} \mathrm{ha}^{-1}\right)$ and imazamox (3.58 $\mathrm{t} \mathrm{ha}^{-1}$ ), which ensured the preservation of 0.83 and 1.06 tons of grains per hectare, or $33 \%$ and $42 \%$, respectively.

The use of herbicides did not lead to a deterioration in soybean quality, in particular, to a significant reduction in protein and oil content. According to Table 3 , the maximum protein content was characteristic of the control options and under the influence of herbicides tended to decrease. Its most significant decrease was observed with imazamox (1.3\%). A higher oil content in the seeds was observed on herbicidal backgrounds; however, its increase was not significant. In our experiments the use of the herbicide bentazone+imazamox even at the highest application rate $\left(2.5 \mathrm{l} \mathrm{ha}^{-1}\right)$ did not cause visible phytotoxicity on a nine-point EWRS scale corresponding to the value of one. Other herbicides also showed a high selectivity for soybeans. Only in 2019, with the application of the herbicide imazamox, minor damage to soybean leaves was obtained in the form of chlorotic spots, which after some time completely disappeared. The phytotoxicity of the preparation was assessed by the second level of toxicity on a scale. Thus, the studies have shown a higher effectiveness of the combined herbicide bentazone+imazamox in comparison with the reference preparations and indicate the feasibility of using it for chemical weeding of soybeans.

\section{CONCLUSIONS}

1. For mixed weeds of soybean crops it is effective to use the combined post-emergence herbicide bentazone+imazamox, which provides an overall reduction in the number of weeds by $84.6-97.0 \%$ and their raw biomass to $89-97 \%$ and increases yields of a crop by $44-52 \%$.

2. Twofold application of bentazone+imazamox at the rate of $0.751 \mathrm{ha}^{-1}$ with an interval of 10-15 days in the phase of the first or second leaf in the crop in a tank mixture with the surfactant Metolate at the rate of $1.01 \mathrm{ha}^{-1}$ is optimal in terms of its efficiency.

3. The synergistic effect of bentazone and imazamox in the original formulation of the herbicide bentazone+imazamox helps to increase the efficiency of its components with minimal phytotoxicity risks.

Received 10 June 2020 Accepted 2 October 2020

\section{REFERENCES}

1. Aulakh J. S., Price A. J., Enloe S. F., Santen E. V., Wehtje G., Patterson W. G. 2012. Integrated Palmer amaranth management in glufosinate-resistant cotton. I. Soil-inversion, high-residue cover crops and herbicide regimes. Agronomy. Vol. 4(2). P. 295-311. DOI: 10.3390/agronomy2040295.

2. Bajwa A. A., Zulfiqar U., Sadia S., Bhowmik P., Chauhan B. S. 2019. A global perspective on the biology, impact and management of Chenopodium album and Chenopodium murale: two troublesome agricultural and environmental weeds. Environmental Science and Pollution Research. Vol. 26(6). P. 53575371. DOI: 10.1007/s11356-018-04104-y.

3. Claerchout S., Recheul D., De Cauwer B. 2015. Sensitivity of Echinochloa crus-galli populations to bread herbicides: a comparison between cropping systems. Weed Research. Vol. 55. P. 470-481.

4. Delchev G., Barakova T. 2018. Efficacy of herbicides, herbicide combinations and herbicide tank 
mixtures on winter forage pea (Pisum sativum L.). Research Journal of Agricultural Science. Vol. 50(1). P. 71-79.

5. Ghanizadeh H., Harrington K. C. 2017. Non-target site mechanisms of resistance to herbicides. Critical Reviews in Plant Sciences. Vol. 36(1). Vol. 24-34. DOI: 10.1080/07352689.2017.1316134.

6. Gitsopoulos T. K., Damalas C. A., Georgoulas I. 2014. Improving diquat efficacy on grasses by adding adjuvants to the spray solution before use. Planta Daninha. Vol. 32(2). P. 355-360. DOI: 10.1590/ S0100-83582014000200013.

7. Gupta V., Mishra S. K., Saraf R. K., Tiwari A. 2017. Efficacy of hand weeding, different pre and postemergence herbicides and their combinations for weed management in soybean crop. Plant Archives. Vol. 17(2). P. 1473-1477.

8. Heap I. 2017. The International Herbicide-Resistant Weed Database [cited 01.06.2020]. Available at: www.weedscience.org

9. Ivanov S. 2019. Weeds and weed control in forage pea: a review. Agricultural Science and Technology. Vol. 11(2). P. 107-112. DOI: 10.15547/ ast.2019.02.017.

10. Ivaschenko O., Ivaschenko O. 2019. Physiological role of epicuticular waxes for plants and their practical significance. Visnyk agrarnoi nauky. Vol. 97(1). P. 12-20. DOI: 10.31073/agrovisnyk201901-02.

11. Jadhav V. T., Kashid N. V. 2019. Integrated weed management in soybean. Indian Journal of Weed Science. Vol. 51(1). P. 81-82. DOI: 10.5958/09748164.2019.00018.2.

12. Karimmojeni H., Barjasteh A., Mousavi R. S., Bazrafshan A. H. 2014. Determination of the critical period of weed control in potato (Solanum tuberosum L.). New Zealand Journal of Crop and Horticultural Science. Vol. 42(3). P. 151-160. DOI: 10.1080/01140671.2013.875926.

13. Marchioretto L. R., Magro T. D. 2017. Weed control and crop selectivity of post-emergence herbicides in common beans. Ciência Rural. Vol. 47(3). P. 1-6. DOI: 10.1590/0103-8478cr20160295.

14. Meseldžija M., Rajković M., Dudić M., Vranešević M., Bezdan A., Jurišić A., Ljevnaić-Mašić B. 2020. Economic feasibility of chemical weed control in soybean production in Serbia. Agronomy. Vol. 10(2). P. 1-12. DOI: 10.3390/agronomy10020291.

15. Kraemer W., Schirmer U., Jeschke P., Witschel M. (eds.). 2012. Modern Crop Protection Compounds. 2nd edn. Weinheim, Germany. P. 29-534. DOI: $10.1002 / 9783527644179$.
16. Norsworthy J. K., Ward S. M., Shaw D. R., Llewellyn R. S., Nichols R. L., Webster T. M., Bradley K. W., Frisvold G., Powles S. B., Burgos N. R., Witt W. W., Barrett M. 2012. Reducing the risks of herbicide resistance: best management practices and recommendations. Weed Science. Vol. 60 (Special Issue). P. 31-62. DOI: 10.1614/WS-D-11-00155.1.

17. Shvartau V. V., Mikhals'kaya L. M. 2013. Herbicides Physico-chemical and Biological Properties. Kyiv, Ukraine. 906 p.

18. Smatana J., Macák M., Týr Š. 2016. Weed control in row crops (Helianthus annuus L., Beta vulgaris L., Zea mays L.) on the interface of agro-climatic conditions of maize and sugar beet growing region. Research Journal of Agricultural Science. Vol. 48(1). P. 226-235.

19. Soltani N., Nourse R. E., Sikkema P. H. 2013. Weed management in white beans with postemergence herbicide tankmixes. Canadian Journal of Plant Science. Vol. 93. P. 669-674. DOI: 10.4141/ CJPS2012-273.

20. Soltys D., Krasuska U., Bogatek R., Gniazdowska A. 2013. Allelochemicals as bioherbicides - present and perspectives. In: Herbicides - Current Research and Case Studies in Use. USA. P. 517-542. DOI: $10.5772 / 56185$.

21. Storkey J., Meyer S., Still K. S., Leuschner C. 2012. The impact of agricultural intensification and landuse change on the European arable flora. Proceedings of the Royal Society, B: Biological Sciences. Vol. 279. P. 1421-1429. DOI: 10.1098/rspb.2011.1686.

22. Tafolla-Arellano J. C., González-León A., TiznadoHernández M. E., Zacarías-García L., Báez-Sañudo R. 2013. Composition, physiology and biosynthesis of plant cuticle. Revista Fitotecnia Mexicana. Vol. 36(1). P. 3-12.

23. Vencill W. K., Nichols R. L., Webster T. M., Soteres J. K., Mallory-Smith C., Burgos N. R., Johnson W. G., McClelland M. R. 2012. Herbicide resistance: Toward an understanding of resistance development and the impact of herbicide-resistant crops. Weed Science. Vol. 60 (Special Issue 1). P. 2-30. DOI: 10.1614/WS-D-11-00206.1.

24. Walsh K. D., Soltani N., Shropshire C., Sikkema P. H. 2015. Weed control in soybean with imazethapyr applied alone or in tank mix with saflufenacil/dimethenamid-P. Weed Science. Vol. 63(1). P. 329-335. DOI: 10.1614/WS-D-14-00076.1.

25. Williams M. M., Nelson R. L. 2014. Vegetable soybean tolerance to bentazon, fomesafen, imazamox, linuron, and sulfentrazone. Weed Technology. Vol. 28(4). P.601-607.DOI: 10.1614/WT-D-14-00019.1. 


\section{Alexey Dykun, Vladimir Zherebko, Maria Dykun \\ HERBICIDŲ EFEKTYVUMAS SOJŲ PASĖLIUI}

\section{Santrauka}

Siekiant didinti pasèlių derlingumą ir gerinti maisto kokybę, būtina tobulinti sojos pasèlių apsaugos nuo piktžolių sistemas. Straipsnyje nagrinejjamas herbicidų biologinis aktyvumas, taip pat techninis ir ekonominis efektyvumas kontroliuojant labiausiai paplitusias ir kenksmingas piktžolių rūšis Ukrainos miškastepių sojų pasẻliuose. Tyrimai atlikti Ukrainos nacionalinio gyvybès ir aplinkos mokslų universiteto Agronominių tyrimų stoties stacionarioje séjomainoje ikurtuose trumpalaikiuose lauko eksperimentuose. Ištirtas herbicidų aktyviụjų medžiagų bentazono, imazamokso ir bentazono + imazamokso mišinių efektyvumas.

Nustatyta, kad sojos pasèliams sudygus naudojamų herbicidų veikliųjų medžiagų mišinys bentazonas + imazamoksas buvo biologiškai aktyvus, veiksmingas ir iš esmès sumažino paplitusių ir santykinai herbicidams atsparių piktžolių skaičių mišriuose sojos pasèliuose. Minètų veikliujų medžiagų $\left(0,751 \mathrm{ha}^{-1}\right)$ ir paviršiaus aktyviosios medžiagos Metolat $\left(1,01\right.$ ha $\left.^{-1}\right)$ mišinio išpurškimas kas dvi savaites (du kartus) piktžolèms esant dviejų ar trijų tikrųjų lapų tarpsnyje buvo efektyviausias. Šis preparatų mišinys sunaikino 89 \% pilkųjų šeryčių (Setaria glauca (Poir.) Roem. \& Schult), 65 \% paprastụjų rietmenių (Echinochloa crus-galli (L.) P. Beauv.), 99 \% plačialapių piktžolių skaičių ir 97 \% jų žaliąją biomasę. Per dvejus tyrimų metus sojos pupelių derlingumas vidutiniškai pasieke 3,82 $\mathrm{t} \mathrm{ha}^{-1}$, arba buvo $34 \%$ didesnis nei kontrolëje be herbicidų. Naudojant herbicidus baltymų ir aliejaus kiekis pupelèse nesumažèjo.

Raktažodžiai: piktžolès, herbicidai, biologinis aktyvumas, efektyvumas, sojos produktyvumas 